\title{
CRISIS IN GOVERNANCE: UNMARKED TAXIS OPERATING IN ABIDJAN, CÔTE D'IVOIRE
}

\author{
ZOUHOULA BI M. RICHARD \\ Department of Geography, Peleforo Gon Coulibaly University, Côte d'Ivoire
}

\begin{abstract}
In Abidjan, unmarked taxis have emerged as an important means of transportation. Operating on inter-municipal transport lines, they have generated the disapproval of metered taxi drivers who are the official beneficiaries of the urban transport services. Denouncing unfair competition, they have initiated strikes in support of the prohibition of unmarked taxis. The sector's regulation, which sets out coercive measures for unmarked taxis, is getting used to the situation as there is a prevailing logic of predation and survival in the sector. This paper intends to reveal that the activity of these taxis contributes to the sluggishness of urban transport governance in Abidjan. Our approach to the situation was based on actors' surveys using interview guides for collecting qualitative data and questionnaires for quantitative data. The results show that the predation and client-based logics of the local authorities favor the conflicts in the regulation and the development of the unmarked taxis' activity. Results also reveal that unmarked taxis receive support from the trade unions in order to become a refugee-based activity in the Ivorian post-crisis context.
\end{abstract}

Keywords: Abidjan, metered taxi, unmarked taxi, governance, predation.

\section{INTRODUCTION}

"If God has torn your mouth, then he would obviously find something to put in it. He will not take for metered taxi and leave for unmarked taxi" (the words of an unmarked taxi driver operating on the transport line 'Treichville-Cocody' in 2013).

From the point of view of unmarked taxis, the abovementioned metaphor and chiasmus reflect the quest for equity. In the Ivorian post-crisis context, where the benefits of the recovered economic growth are partially shared, exclusion, which is always seen as an injustice, is pointed out to legitimize a specific position, even thought that position is illegal. Thus, if resourcefulness (due to waged employment crisis) is used by this driver as a pretext to claim for equity, perceived in this context as the freedom to work, metered taxis on the contrary declare a drop in the revenue, following the competition and the high operating costs, and require the prohibition of unmarked taxis. On the altar of the fight against poverty, equity ultimately means, for one group, the pursuit of the transport activity without any form of barriers and, for the other, the strict enforcement of public transport regulations.

Indeed, spurred by population and spatial growth, Abidjan has moved from offering one kind of taxi to three, including metered taxis, municipal taxis and unmarked taxis. If metered taxis and municipal taxis are legal, the other group is not. Popularized by the practice of paying carpooling on inter-municipal transport lines, this situation is more a product of urban resourcefulness [1] than a real need on this section of urban transport lines. Mayors, in search of their own resources, have assimilated them to taxable activities without considering the contradiction with the regulatory provisions in the sector. The issuance of the municipal parking card, under the pretext of identifying loading stations in the municipal areas, grants legitimacy to that practice. Metered taxi drivers are denouncing this situation, but the town councils are using the argument of electoral deadlines to maintain the status quo. Moreover, the sluggishness of the Ivorian political landscape compels other regulation actors to refrain from challenging the local authorities; a situation 
which is seen by unmarked taxis as a blanc-seing. Finally, they use the argument of their functional utility toward urban impoverishment to claim, despite a different status, the same treatment as those received by other types of transport. Metered taxis, on the contrary, call for authorities' actions in view of the following three objectives: survival, coping with competition and updating the sector's regulatory texts.

\section{METHODOLOGY}

There are three types of taxis in Abidjan (metered taxi, municipal taxi and unmarked taxi). Since the territorial collectivities' revolt, which led to the dissolution of the Urban Transport Agency (AGETU) in 2013, several actors have emerged in the sector. For the metered taxi, the only authorized taxi since the independence, the District of Abidjan is the regulatory authority concerning, for example, the issuance of transport documents and parking cards; it is an inter-municipal transport service. As for the municipal taxi, which was authorized at the beginning of the communalization policy in 1980, the municipalities ensure the regulation within the municipal areas boundaries, for the issuance of transport documents and parking cards. The municipalities authorize professionals to create and operate transport lines. The unmarked taxi is an illegal transport service which, though prohibited, has been tolerated since the civil war (2002-2011). Each town hall, for where there is departure and/or destination, issues a parking card. But the transport lines are created by the trade unions which compel operators to pay a (single daily) tax for entrance and operation.

This paper aims to conduct a descriptive analysis of the sluggishness in taxi governance in Abidjan. The main assumption is that the attraction for the financial resources generated by unmarked taxis is at the heart of conflicts in regulation. The second assumption considers the unmarked taxis as a pretext used by professionals to implement a regulation which only favours operators. In order to confirm or negate these assumptions, the author conducted two types of surveys (from January to March 2013) in four municipalities in Abidjan: Cocody, Koumassi, Marcory and Treichville. The first surveys (quantitative) involved a total number of 500 taxi clients and 89 unmarked taxi operators, randomly selected at the loading stations [2]. The objective at this level was to identify the clients, especially those in socio-professional categories, who use this transport. It was also aimed at revealing the social interest and the economic return. The second survey (qualitative) focused on the analysis of trade union actors' discourse in the stations. It also analysed documents from territorial collectivities and from the former Urban Transport Agency (AGETU). The research yielded three results: the dispute over the taxis' reform led by territorial collectivities accounts for the appearance and the pursuit of unmarked taxis operation in the public transport landscape; the management of unmarked taxis by trade unions is the result of the disputes in the regulation; and the unmarked taxis represent an important refugee-based activity in the economic-crisis context.

\section{TAXI REFORM CHALLENGED BY TERRITORIAL COLLECTIVITIES}

\subsection{Weakening of the state: first cause}

The decentralization policy, launched in 1980, has created the City of Abidjan (now District) and ten municipalities. As far as taxis are concerned, competences are shared according to the distinction between urban and municipal roads. The management of urban interest roads belongs to the District, and that of the municipal roads, to the town halls [3]. Taxi management abides by this initial distinction. Metered taxis operating on the urban 
transport lines are managed by the District, whereas the management of municipal taxis lies in the hands of mayors of the municipal area. The level of responsibility related to the operation area ultimately leads to the coordination principle between the two bodies for issuing acts [4]. This configuration has only been effective over the years 1980-1990 during which the economy of Côte d'Ivoire resisted the crisis.

The social, political and economic context of the 1990s and 2000s has changed the situation. The political protest and the worsening of the economic crisis of the years 1990-2000 were followed by the coup d'état of 1999 and the military and civil crisis (2002-2011), etc. During the two decades, there was a weakening of the state, characterized by distrust of public authority, prevarication, corruption, clientelism, unemployment, poverty, etc. At the level of public transport, many unemployed and laid-off workers are getting involved in the transport activity. Because of a lack of sufficient capital to acquire the metered taxis or municipal taxis, they choose unmarked taxis, for which authorization conditions seem flexible [5]. In fact, the municipal parking tax and arrangements with the police are suffice enough for them to operate. The unmarked taxi represents an important source of financial revenues for elected local authorities; therefore, they increase the issuance of transport documents, pretending to ignore the fact that this type of transport operates on inter-municipal transport lines.

The appearance of such transport in the urban transport network and the failure of SOTU represent one of the causes of the dysfunctions denounced by the sectorial adjustment program for transports (CI-PAST). The creation of the Urban Transport Agency (Agetu) reflects the desire to address the issue, but the decree establishing the agency is a source of conflict. It grants the same prerogatives to the agency without removing those of the District and the municipalities. Local elected authorities ingeniously raise the issue of the authority empowered to issue transport authorizations by requesting operators to gain authorizations from their departments, under the threat of vehicle impoundments [6]. The number of places granted to the mayors within the agency's board of directors has little effect on the revolt; the latter claiming the superiority of the law on the decree to deny the authority of the agency.

Moreover, the context of the military and civil crisis, and the contradictions in the laws of finance of the years 2004, 2005 and 2007, exacerbate disputes and reinforce the fragmentation of responsibilities in the sector. Thus, even though Article 42 of the tax schedule of the ordinance no. 2007-488 of 31 May 2007 removes the municipal parking tax in favor of the AGETU's urban transport tax (TTU), elected local authorities still apply parking taxes in the municipalities. Even the coming to power of President Alassane Ouattara, a period considered as the assertion of the state authority, has not changed the situation. The unsuccessful warnings of the Ministers of Transport and Interior to local authorities illustrate the ability of the latter's to bypass the rules under the pretext of collecting the financial resources generated in municipal areas.

\subsection{Capture of financial resources generated by unmarked taxis: second cause}

In addition to the disputes on the superiority of the law over the decree, the town councils also refuse to transfer the management of the revenues from the transport authorizations issuance [7]. According to the former AGETU (2009), there are 17,400 metered taxis, 5800 municipal taxis and 7000 unmarked taxis in Abidjan. The first metered taxi's authorization issuance is estimated to be 228 euros and the renewal of one costs 152 euros. For municipal taxis and unmarked taxis, the parking tax is 121.60 euros. Revenues from the various transport authorizations are estimated to be more than 9,120,000 euros per year. So, the 
confiscation of the TTU and the parking tax (DS) is a major challenge for the District and the municipalities. However, the creation of the AGETU creates uncertainty about the collection of these revenues, which are considered by the town councils as their property. In fact, the Agency's budget is mostly made up of revenue from transport management and public subsidy. The mayors then raise a controversy over the duality of resources for funding that budget, thus implicitly revealing their strategy of taxes confiscation [8]. Whilst the municipalities estimate this budget at 2,280,000 euros, the AGETU on the contrary declare an estimate of 1,073,120 euros, representing 3\% of the District's budget. Such a gap leads the agency to legitimately consider itself as a victim of a political interpretation of the taxes issue and the municipalities also considered themselves as being deprived of an important source of income.

To establish more coherence in the governance of taxis, the 2004 finance law grants $40 \%$ of the taxes to the municipalities and $60 \%$ to the Agetu. This distribution gives rise to the wrath of the municipalities. So, with the support of parliamentary relays, they won their case. Considering that the former one does not sufficiently take into account the budgetary constraints of the municipalities and the district of Abidjan, the tax schedule of the 2005 financial law contradicts the distribution key of 2004. The new law grants $60 \%$ of the taxes to the territorial collectivities, $40 \%$ to the Agetu, and associates to the agency a regulatory body for managing the taxes. The situation reversal holds the Agetu in the position of registration office and makes it dependent on the transport policies of the municipalities which intend to get back the overall management of the taxes. The 2007 finance law keeps the sharing in favor of mayors but assigns tax collection to the Directorate General of the taxes (DGI). So, mayors receive $52 \%$ of the taxes, the Agetu $38 \%$ and the DGI $10 \%$. The hope of returning to normality with the coming to power of President Alassane Ouattara leads to the adoption of a new distribution key in the finance law of 2013. Thus, "in order [...] to allow the AGETU to have sufficient resources so as to carry out its mission of regulating urban transport activity, proposals are set forth, on the one hand, to increase from $38 \%$ to $65 \%$ the share of the tax products allocated to AGETU and, on the other hand, to reduce the amounts paid back to the District and the Directorate General of the Taxes" (Article 23 of the Finance Law 2013). The territorial collectivities are ranked at $30 \%$ and the DGI, at $5 \%$.

Mayors' hostility towards the implementation of the 2013 finance law hinders the agency's expectations, ultimately compelling the Ministry to decide upon dissolution. So, the Agetu was dissolved in 2014. With the elimination of governance competition, the town councils have increased the issuance of parking authorizations, a document used by unmarked taxis to operate. Finally, while waiting for a new body to be established with respect to the law governing inland transport (LOTI), the metered taxis are subject to the municipalities' logic of financial resources collection, a situation which is used by trade unions from the informal sector to implement an operator-based governance.

\section{TRADE UNION GOVERNANCE FOR UNMARKED TAXIS}

4.1 The management of the resources generated by the unmarked taxis, the cause of trade-union-based governance

There are two types of trade union members in the informal transport sector. The first type is a union member or an operator, who has grown old in the activity and expects to receive, at the end of the day, a 'nest egg' collected at the stations from the active operators. The second type is an operator who has to pay trade union rights in order to operate. Both cases 
highlight the mandatory collection of tax on behalf of the operator. Thus, unlike usual trade union practices, membership is based on the ability of trade union members to collect "their tax" under the pretext of solidarity and professionals' interest defense against the state and unlawful control carried out by the police.

With the lack of actions against trade union practices, the municipality becomes the accomplice of unmarked taxis, and continues as usual to legitimize them through the issuance of transport documents and by granting authorization to trade unions in order to manage taxi stations located within the municipality. For trade unions, stations are now a space at stake. Finally, considered as a lucrative activity, trade unions, as described above, attract many unemployed persons. There are more than 200 trade unions in Abidjan. They take advantage of the sluggishness in the official governance in order to monopolize the management of unmarked taxis, which are subject to taxes collected by the trade union; simply because when the trade union tells you not to take on passengers, you can't.

Apart from the tax related to the right of operation on a transport line, which is paid at the beginning of the activity, the other taxes are collected on a daily basis. The trade union ticket is a fixed tax paid daily by the unmarked taxi. Estimated between 0.15 euro and 0.46 euros, this amount is payable (only once) to all the trade unions in charge of the transport lines. Concerning the tax on loading, its amount (between 0.08 and 0.61 euros) depends on the vehicle's capacity and the loading of the passengers at the beginning of the lines. Some trade union leaders declare that they collect 7600 euros every day, representing an annual amount of 4,256,000,000 euros. But that money does not go anywhere. When you get it, you keep it for yourself. The strategy of trade unions establishment is traditionally based on the issuance of tickets bearing the sign of trade unions. But the proliferation of informal stations has definitely changed the situation, hence forcing the corporatist structures to establish operation program lists to secure the revenue of individuals because it is an honor to get the money from transport line tax.

Collecting the revenue of unmarked taxis leads to disputes within the sector. Generally, this situation opposes a newcomer to all the trade unions already operating in the station. Considered as an intruder, the new trade union is accused (by the former unions) of causing the loss of revenues [9]. To operate, the new trade union needs the town council's authorization, the order of the judge and police and gendarme forces. But the support does not last long as security in those places is expensive. Therefore, the new trade union, which intends to operate in the municipal station, creates a small army of hooligans. The outcome of these conflicts shows the ability or inability of the newcomer to benefit from these resources and reflects an underlying organization in the stations.

\subsection{A rotation system to limit violence, still inefficient}

Two trade unions have expressed the corporation's claims for years. Those trade unions are the Ivoirian National Union of Travelers and Goods Carriers (SNVTM-CI) and the Ivoirian Road Transporter Union (SNTT-CI). The tax collection system for passenger's transportation has operated in a peaceful environment. But at the beginning of the 1990s, following the multi-party system, the number of trade unions has significantly increased in the sector. This situation leads to violence, mainly because of the desire to control the "Jackpot" produced in the stations. Theoretically, trade unions earn their living from tickets issued every day. But from the point of view of a trade union leader, it is up to the drivers to decide which trade union to join. So, a situation of uncertainty emerges, leading to performance pressures; which consist of recruiting people able to impose their authority and secure the collection of trade union rights inside the stations. In a sector where the 
exclusion of the state is advocated, the strategy adopted leads to violent brawls for the control of the stations. To limit such violence, the professionals have agreed on a rotation system in the stations, which gives to every trade union (transporter and driver) one day of collection per week. If, for example, a transporter trade union operates on a Sunday, it must wait until the next Saturday of the following week to operate again. The collection program for the drivers' trade unions is as follows: one day of operation for three groups, with three days of rest. But the proliferation of trade unions has a negative impact on this arrangement, because it allows the daily presence of trade unions in the stations. This system nevertheless allows the trade union employee to offer his services to several trade unions and increase his earnings.

This agreement does not prevent the occurrence of violent raids for stations control. Those raids are sometimes reported by the media. The objective in doing so is to eliminate competition. This situation causes some public-order disturbances requiring the intervention of the police and the municipal authorities; something that the trade unions reject. To limit such situations, municipalities issue orders in view of controlling the access of trade unions to stations. All unions then use all kinds of arguments (order, security, cessation of violence, regular payment of parking cards) to be accredited. Even if the procedure seems regular, some trade unions use the argument of undue parking cards control to create conflicts between the designated trade unions and the town councils.

\section{UNMARKED TAXIS: \\ AVAILABLE TRANSPORT AND REFUGEE-BASED ACTIVITIES}

\subsection{Unmarked taxis: accessible and available transport}

The urban transport supply deficit and the increase in urban transport demand favor for the operation of unmarked taxis in the transport services of Abidjan. Indeed, the fleet of Sotra is still insufficient (900 vehicles in 2015) and the metered taxis are far from being accessible to the majority of city dwellers. This situation increases the need for transport in the Ivorian economic capital city characterized by a stronger demography $(4,395,245$ inhabitants [10]). Even though the end of the military and civil crisis has been followed by impoverishment, the need for people in public transport is far from being less important. In the absence of mass urban transport with a low cost, the use of accessible and available transport is becoming widespread. The losses suffered by Sotra during the post-electoral crisis account for the size of the company's bus fleet (300 vehicles in 2016) and the metered taxi still appears as a type of transport reserved to an elite. Unmarked taxis take advantage of these circumstances to register a high demand, as shown in Table 1.

Table 1: Transports users surveyed on the basis of the type of transport.

\begin{tabular}{|l|l|l|l|l|l|}
\hline $\begin{array}{l}\text { Mype of } \\
\text { transport }\end{array}$ & Cocody & Koumassi & Marcory & Treichville & Total \\
\hline Metered taxis & 29 & 46 & 18 & 40 & 133 \\
\hline Unmarked taxis & 83 & 117 & 93 & 74 & 367 \\
\hline Total & 112 & 163 & 111 & 114 & 500 \\
\hline
\end{tabular}


This table reveals that out of 500 respondents, 367 people use unmarked taxis compared to 133 persons using metered taxis. The data collection site is made up of areas where unmarked taxis are mostly demanded. In this type of transport, the trip costs between 0.46 and 1.37 euros.

Ultimately, car-pooling is the source of the unmarked taxis' popularity. On the contrary, the metered taxi is an individual form of transport compelled to comply with modern supply requirements; a situation which has a negative impact on its competitiveness. It also requires a significant initial investment with high operation costs. Endangered by competition, the metered taxis fall back on the lines of the so-call transport with the hope of increasing their revenue. So, though the stations are created by trade unions in order to collect their taxes on unmarked taxis, metered taxis also operate in the same area, accepting militarization.

According to our survey data, all of the social categories use unmarked taxis. Out of 500 respondents, 416 persons use this type of transport for professional reasons, whereas 84 use it for social reasons. Public and private administration employees are the occupational categories which mostly request this type of transport. Even if this type of transport is mostly chosen by civil servants, the table shows that poor social categories (students, unemployed/retired people and housewives/housekeepers) also use it. This fact highlights the popularity and availability of such transport in a city in search of punctuality in transport.

In Abidjan, where transport is important for economic and social life, results show that unmarked taxis are still operating because they are the most available type of transport. All types of occupations use that type transport, with a higher percentage of civil servants who, though they represent less than $40 \%$ of the labor force, are more than $50 \%$ of the unmarked taxi users. With the change in the political regime, followed by a takeover by the State, unmarked taxis use socio-economic reasons as a pretext to continue operating.

\subsection{Social impact of the unmarked taxis' emergence}

Over the military and civil crisis decade (2002-2011), confusion has emerged between the service of unmarked taxis and that of metered taxis. This situation is certainly favored by the context of distrust for the authority and that of impunity. With the end of the crisis, metered taxis are claiming the enforcement of the texts regulating the sector. Yet, such forms of transport are the sign of the Abidjan population's resilience to poverty. Firstly, the unmarked taxi is considered a refugee-based activity in the waged employment crisis context. Secondly, it represents a symbol of free competition in a city where the option for choosing an official metered taxi is facing difficulties [11].

Table 2: Transport users surveyed on the basis of their professional status.

\begin{tabular}{|l|l|l|l|l|l|l|l|l|}
\hline & $\begin{array}{l}\text { Pupil / } \\
\text { Student }\end{array}$ & $\begin{array}{l}\text { Unemployed / } \\
\text { Retired }\end{array}$ & $\begin{array}{l}\text { Housewife / } \\
\text { housemaid }\end{array}$ & Trader & Artisan & $\begin{array}{l}\text { Public } \\
\text { administration }\end{array}$ & $\begin{array}{l}\text { Private } \\
\text { administration }\end{array}$ & Total \\
\hline $\begin{array}{l}\text { Metered } \\
\text { taxis }\end{array}$ & 2 & - & - & 24 & - & 20 & 38 & 84 \\
\hline $\begin{array}{l}\text { Unmarked } \\
\text { taxis }\end{array}$ & 27 & 17 & 11 & 67 & 47 & 97 & 150 & 416 \\
\hline Total & 29 & 17 & 11 & 91 & 47 & 117 & 188 & 500 \\
\hline
\end{tabular}


Beyond these resilient aspects, this kind of transport continues to operate because of hesitations in the regulation. In an Ivorian society where the state is the main employer, this activity ensures a peaceful urban environment and provides guaranteed customers to the authorities.

Table 3 reveals that laid-off private sector workers account for more than half of the unmarked taxi operators' total number (48 persons). The closure and relocation of many factories and services due to civil war resulted in significant dismissals. For those persons, transport activity has become a source of financial income. With the country's reconstruction process, they pursue the activity with the hope of the activity's economic revitalization. The operators' status of the surveyed drivers (70 persons) confirms this fact. As suggested by the quoted (from a driver) in the introduction, economic contingencies force many people to violate the prohibition measures, using trickery or receiving the complicity of the regulation.

The operators represent the majority of the surveyed population. This situation is due to the acquisition of vehicles, which is still out of reach for many people. The presence of other social categories shows that the activity is open to anyone. So, except for laid-off workers from the private sector, operators from the category of "Young people looking for employment" are the most numerous ( 24 persons). Their presence reinforces the status of refugee-based activity acquired so far by unmarked taxis. They provide employment and financial resources to many persons in a context characterized by economic recovery difficulties. Despite unfavorable regulations, the operators are considered as a professional body, even if some persons working in the sector are still waiting for economic recovery.

\subsection{Economic impact of unmarked taxis}

Even if under the pretext of regulation enforcement, metered taxis try to prohibit the unmarked taxis, the relevant actors are apparently unaware of the economic interest. In fact, the activity provides significant financial income. The paid parking taxes are used to fund town councils' budgets. The financial resources generated also justify the policies adopted during elections. So, to guarantee the regular payment of taxes, some town councils enter into agreement with trade unions. This is a strategy adopted by town councils to identify the number of operating vehicles. It is also a professional carte blanche for the control of resources from the activity.

For owners and operators, the unmarked taxi is a major source of financial income. In the opinion of the surveyed operators, the working day starts at 6 am and ends at $10 \mathrm{pm}$. In Abidjan, the movement of people complies with the timeframes set by the world of work: 6-9 am when going to work and 5.30-9.30 pm when coming from work. During rush

Table 3: Status of the drivers.

\begin{tabular}{|l|l|l|l|}
\hline & Owner & Operator & Total \\
\hline Young people looking for employment & - & 24 & 24 \\
\hline Students & 1 & & 1 \\
\hline Layoffs of the private sector & 14 & 34 & 48 \\
\hline Casuals & 04 & 12 & 16 \\
\hline Total & 19 & 70 & 89 \\
\hline
\end{tabular}


hours, there is a strong demand for all types of transport, especially for unmarked taxis. A taxi often requires three drivers: the incumbent, an official assistant and a non-official assistant. Generally, the incumbent works during rush hours to complete the daily revenue. The off-peak periods are assigned to the assistants; that is why vehicles work for a long period of time (16 hours/day). For the interviewed operators, the daily revenue is 45.60 euros. But the amount declared is 34.96 euros; that is, 19.76 euros for the owner and 15.20 euros for purchasing fuel for the next day. The remaining amount (10.64 euros) is used for clientelism, trade union tax payment and household responsibilities. In the informal transport sector, the operator's employment contract is generally unwritten. The operator's remuneration is either based on the principle of daily revenue, or on that of monthly remuneration (121.60 euros per month).

With such distribution of the generated resources, owners get a return on investment after one year of the vehicle's operation, a return which is estimated at 5690.88 euros, representing 474.24 euros per month and 118.56 euros for a week of six working days. The operator must work to get revenue which is 30,40 euros higher than the Ivorian SMIG (91.20 euros). Sometimes, some operators perform additional transport activity (private transport, rentals, etc.) to increase their incomes.

\section{CONCLUSION}

In Abidjan, the unmarked taxis continue to operate by adapting themselves to the population's movement needs, by accepting to pay taxes to municipalities and by becoming a refugee-based activity in the context of a waged employment crisis.

The increase in the number of strikes is certainly a strategy for metered taxis to claim the immediate enforcement of the prohibition orders issued against unmarked taxis operating on inter-municipal transport lines. But in the Ivorian context, where clientelism is still significant, the situation turns the competition between the metered taxi and the unmarked taxi into a more and more antagonistic competition, with each group of actors receiving powerful support in advance. Most certainly, the sustained dispute helps the population to compare the two types of transport modes and use the most affordable one in a city seriously affected by the 2011 violent post-election crisis.

Far from being the most appropriate answer to the shortage in the Abidjan transport supply, the unmarked taxi highlights the violation of rules; a phenomenon which became widespread during the decade of civil war. It is a symbol of the weakening of the State, which is so far unable to eliminate this type of transport, despite several decisions. So, objections requesting the enforcement of the regulation are dissolved under the pretext of free competition; a pretext which has deprived competent services of their voice. In Abidjan, this situation certainly leads to an increase in the supply of transport, but it also creates many conflicts, often resulting in death.

\section{REFERENCES}

[1] Couret, D., Territoires urbains et espace public à Abidjan: quand gestion urbaine et revendications citadines composent. Le Modèle Ivoirien en Question: Crise, Ajustements, Recomposition, eds B. Contamin \& H. Memel-Fotê, Karthala: Paris, pp. 429-458, 1997.

[2] Fortin, M.F., Fondements et Étapes du Processus de Recherche: Méthode Quantitative et Qualitative, 2nd ed., Chenelière-Education, 656 pp., 2010.

[3] Agence Japonaise de la Cooperation Internationale (Jica), Ministere de la Construction, du Logement, de l'Assainissement et de l'Urbanisme, Schéma Directeur d'Urbanisme du Grand Abidjan en République de Côte d'Ivoire (SDUGA), 
Rapport final, Volume III: Schéma Directeur des Transports Urbains du Grand Abidjan, Partie 6: Schéma Directeur des Transports Urbains le Grand Abidjan, Abidjan, 2015.

[4] Meite, Y., Gouvernance du transport urbain et mobilité durable dans le District d'Abidjan, Université de Strasbourg, Ecole doctorale 519, UR SAGE, 326 pp., 2014.

[5] Steck, Jean-Fabien, La rue Africaine, territoire de l'informel? Flux, 4-1(66-67), pp. 73-86, 2007.

[6] Journal "Le Patriote", Côte d'Ivoire: Cartes de stationnement du district d'Abidjan: Amondji prêt à mettre des véhicules en fourrière. Accessed on: 13 Mar. 2004.

[7] Zouhoula Bi, M.R., La gare interurbaine au cœur des conflits entre la mairie d'Adjamé et la ville d'Abidjan. Abidjan, Dakar: Des Villes à Vendre? La Privatisation Made in Africa des Services Urbains, L'Harmattan, pp. 169-175, 2008.

[8] Lombard, J. \& Zouhoula Bi, M.R., Minibus et taxis à Abidjan:50 ans de lutte pour la reconnaissance du secteur privé. Abidjan, Dakar: Des Villes à Vendre? La Privatisation Made in Africa des Services Urbains, L'Harmattan, pp. 43-56, 2008.

[9] Lombard, J. \& Zouhoula Bi, M.R., Des instances de régulation pour quoi faire? Avenir délicat dans le transport urbain (Abidjan, Dakar). Abidjan, Dakar: Des Villes à Vendre? La Privatisation Made in Africa des Services Urbains, L'Harmattan, pp. 195-213, 2008.

[10] Institut Nationale de la Statistiques, Recensement Générale de la Population et de l'Habitat (RGPH), Abidjan, 2014.

[11] Zouhoula Bi, M.R., Guerre civile, logiques économiques: l'essor des motos-taxis à Korhogo. Journal des Sciences Sociales, (11), 171 pp., 2014. 